\title{
Geochemical structure of the oldest Pacific lithosphere
}

\author{
KAZUTO MIKUNI ${ }^{1}$, NAOTO HIRANO ${ }^{1}$, NORIKATSU \\ AKIZAWA $^{2}$, SHIKI MACHIDA ${ }^{3}$, AKIHIRO TAMURA ${ }^{4}$ AND \\ TOMOAKI MORISHITA ${ }^{4}$ \\ ${ }^{1}$ Tohoku University \\ ${ }^{2}$ The University of Tokyo \\ ${ }^{3}$ Chiba Institute of Technology \\ ${ }^{4}$ Kanazawa University \\ Presenting Author: kazuto.mikuni.t6@dc.tohoku.ac.jp
}

The geochemical/petrological information of lithospheric mantle below the Pacific Ocean has ever been highly limited to the areas of transform faults near the mid-ocean ridge (abyssal peridotite) and oceanic hotspots providing xenoliths. More recently, the lherzolitic xenoliths and olivine xenocrysts in petitspot lavas on $130 \mathrm{Ma}$ lithospheric mantle suggested the metasomatized domains of northwestern Pacific Plate. Meanwhile, a subseafloor petit-spot (small conical knoll) cluster is newly discovered in the southeast of Minamitorishima (Marcus) Island on the oldest portion of western Pacific Plate, where the age is approximately $160 \mathrm{Ma}$. We newly report here the peridotite and pyroxenite xenoliths, and pyroxene xenocrysts transported to the ocean floor through the petit-spot volcanisms, thus directly providing petrological and geochemical information of the oldest Pacific lithosphere. This study presents in-situ chemical compositions, determined using an electron microprobe and a laser ablation inductively coupled plasma mass spectrometry, of xenoliths and xenocrysts.

Most of the clinopyroxene composing pyroxenites and peridotites are Ti-rich Al-augite, indicating compositional difference with the depleted residual peridotite. Ti-rich Al-augite is generally originated from phenocryst crystallized at high pressure, cumulate from alkalic magma or metasomatic vein in lithospheric mantle. In the case of our sample, the petrographic characteristics of clinopyroxene (e.g., lamellae) suggest that these are not phenocryst or cumulate but xenoliths from metasomatic mantle. Moreover, the trace element compositions of clinopyroxene designate the enriched composition in the light rare-earth elements as well as those of xenoliths from previously reported petit-spots on NW Pacific Plate. Otherwise, a peridotite xenolith notably shows highly depleted composition resembling the residual mantle with lower concentration of heavy rare earth elements than the present lithospheric mantle of Pacific Plate. The presence of the depleted xenolith plausibly indicates higher degrees of mantle melting at the mid-ocean ridge during Jurassic time ( $160 \mathrm{Ma})$ when the Pacific Plate started forming within the Panthalassa Ocean. 